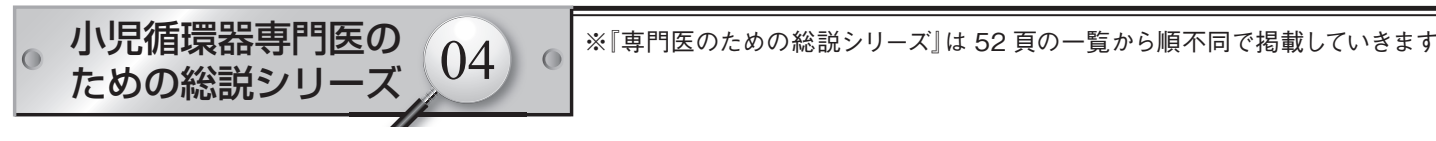

\title{
検查・処置における鎮静・鎮痛
}

| 糟谷 周吾
国立成育医療研究センター手術集中治療部

\section{Procedural Sedation and Analgesia for Children}

Shugo Kasuya

Department of Anesthesia and ICU, National Center for Child Health and Development, Tokyo, Japan

Procedural sedation and analgesia in children require a systematic approach to establish patient safety. Failure to rescue the patient and the absence of system issues have been key components in sedation disasters in the past. Points of interest include informed consent, pre-sedation history taking, and physical examinations especially focused on the airway, proper fasting prior to elective procedures, appropriate monitoring and emergency equipment, backup emergency services, independent personnel responsible only to monitor and assist the patient during the procedure, documentation, and appropriate monitoring and staffing during recovery. Issues are essentially the same in children with heart disease and are described here.

\section{要旨}

鎮静鎮痛 (procedural sedation and analgesia：PSA)を安全に行うためには, システム的アプローチをとることが大切 である.PSA は, 基礎疾患を背景に持つ患者に対する目的(処置や検査)に対して, それらを安全かつ快適に遂行する ための医学的介入である。したがってPSAの利点と合併症について十分理解し, 目的とする処置や検査への利益と 天秤にかけたうえで，その具体的方法を決定し，管理を行うことが望ましい.

\section{はじめに}

\section{1. 小児のガイドライン}

小児鎮静のガイドラインは, 鎮静に伴う死亡事故を 経て 1985 年にはじめて米国小児科学会 (AAP)より出 版された。このガイドラインには麻酔科学という言葉 が入っていたため他の専門科から興味を持たれること は少なく，広く普及しなかった。その後 1992 年, 2002 年の改訂を経て, 現状の 2006 年ガイドラインに続 く1,2).そのコンセプトは, “rescue”と “systems issue”の 重要視である. 米国における過去の鎮静事故の反省か ら, 最大の事故要因は問題が生じた場合の “rescue”の 欠如であり，また麻酔事故と同じく“systems issue” の構 造的問題によることが指摘されている2).

成人を対象とした鎮静鎮痛 (procedural sedation and analgesia：PSA）については, 米国3,4)やオーストラリ $ア^{5)}$ から, 小児においては米国6), 英国7), スコットラン
ド8），南アフリカ9などのさまざまな団体が作成してい る10). 国内で PSA 全般を扱うガイドラインはないが, MRI 検査時の鎮静に関する共同提言があり，その基本 概念はあらゆる鎮静に共通し重要であるため参考にで きる11).

2. 除外

ここでは, 監視下鎮静(麻酔)管理 (monitored anesthesia care : MAC ${ }^{12)}$, 術後の鎮静鎮痛, 人工呼吸中の鎮静鎮 痛, 重症患者における痛み・不穏・せん妄, がん疼痛, 慢性疼痛は含まない。それぞれ各学会等から出版され たガイドラインなどを参照していただきたい.

3. 鎮静レベル

一般に鎮静の深さと身体的反応は, 主に 3 段階で minimal, moderate, deep と分類され, それらは「continuum：一連 
Table 1 Continuum of depth of sedation: definition of general anesthesia and levels of sedation/analgesia*

\begin{tabular}{l|l|l|l|l|l}
\hline & $\begin{array}{l}\text { Minimal } \\
\text { Sedation } \\
\text { Anxiolysis }\end{array}$ & $\begin{array}{l}\text { Moderate } \\
\text { Sedation/ } \\
\text { Analgesia }\end{array}$ & $\begin{array}{l}\text { Deep Sedation/ } \\
\text { Analgesia }\end{array}$ & $\begin{array}{l}\text { General } \\
\text { Anesthesia }\end{array}$ & $\begin{array}{l}\text { Dissociative } \\
\text { sedation*** }\end{array}$ \\
\hline Responsiveness & $\begin{array}{l}\text { Normal } \\
\text { response to } \\
\text { verbal } \\
\text { stimulation }\end{array}$ & $\begin{array}{l}\text { Purposeful } \\
\text { response to } \\
\text { verbal or tactile } \\
\text { stimulation }\end{array}$ & $\begin{array}{l}\text { Purposeful } \\
\text { response to following } \\
\text { repeated or painful } \\
\text { stimulation }\end{array}$ & $\begin{array}{l}\text { Unarousable } \\
\text { even with painful } \\
\text { stimulus }\end{array}$ & $\begin{array}{l}\text { A trance-like } \\
\text { cataleptic state, with } \\
\text { analgesia and } \\
\text { anmesia }\end{array}$ \\
\hline Airway & Unaffected & $\begin{array}{l}\text { No intervention } \\
\text { required }\end{array}$ & $\begin{array}{l}\text { Intervention may be } \\
\text { required }\end{array}$ & $\begin{array}{l}\text { Intervention often } \\
\text { required }\end{array}$ & $\begin{array}{l}\text { retention of protected } \\
\text { aiway reflex }\end{array}$ \\
\hline $\begin{array}{l}\text { Spontaneous } \\
\text { Ventilation }\end{array}$ & Unaffected & Adequate & May be inadequate & $\begin{array}{l}\text { Frequently } \\
\text { inadequate }\end{array}$ & May be adequate \\
\hline $\begin{array}{l}\text { Cardiovascular } \\
\text { Function }\end{array}$ & Unaffected & $\begin{array}{l}\text { Usually } \\
\text { maintained }\end{array}$ & Usually maintained & May be impaired & Usually maintained \\
\hline
\end{tabular}

*Monitored Anesthesia Care does not describe the continuum of depth of sedation, rather it describes "a specific anesthesia service in which an anesthesiologist has been requested to participate in the care of a patient undergoing a diagnostic or therapeutic procedure".

**Reflex withdrawal from a painful stimulus is not considered a purposeful response.

***Dissociative sedation is not in the continuum. This is an area of controversy wherein ketamin is administered for deep sedation or independently categorized as dissociative sedation.

Modified from Continuum of Depth of Sedation. 2009. (Accessed at https://www.asahq.org/For-Members/Standards-Guidelines-and-Statements. aspx), Krauss B, Green SM. Procedural sedation and analgesia in children. Lancet 2006; 367: 766-780.

のもの」で境界は曖昧である6,13).またケ夕ミンの使用で は, dissociative sedation という状態となる. PSAの施行 前には, 目的とする鎮静レベルを決定しておく(Table 1).

\section{PSA の目的}

不安や恐怖の軽減, 疼痛の制御, 体動の抑制・最小化, 安全の確保，回復の確認の 5 点である.

\section{PSA の危険性について}

最優先事項は，患者の安全確保である。しかしなが ら,「安全というものは存在しない。この世に存在する のは危険だけ。危険を避けられて結果的に何も起きな かった，というのが安全である」14）。

鎮静は自然睡眠と異なり，気道閉塞，呼吸停止，心停 止の危険性を伴う，小巟を対象とした日本の大規模な鎮 静に関する報告はないが, 2011 年の日本小児科学会医 療安全委員会の「MRI 検査の鎮静管理に関する実態調 査」では，アンケートに回答した 416 施設中，過去の心 停止を経験したのは 3 施設，呼吸停止を経験した施設は 75 施設に及び，検査中のモニター装着がない施設は $23 \%$, 検査中の医師または看護師の付き添いがない施設 は $25 \%$, 検査前の絶飲食基準がない施設は $63 \%$, 検査 中の監視デー夕記録がない施設が $80 \%$ であったと報告 された15)。また the Pediatric Sedation Research Consortium による北米多施設の後方視的検討に基づく報告では, 使用薬剂・鎮静担当医・検査処置の内容はさまざまで あったが, 手術室外の PSA 1 万例あたりの心停止は 0.3
〜 0.4, 無呼吸は $24.3 \sim 143,90 \%$ 以下の $\mathrm{SPO}_{2}$ 低下は 156 ～ 716 であった ${ }^{16,17)}$. 一方, 全身麻酔での小览全例 を対象とした後方視的検討では, 麻酔に起因する心停 止は 1 万例あたり 0.65 と報告される18)。この中には心 臓手術, 大量出血, 重症例, 新生児緊急症例などが含ま れることを考慮すれば, PSAにおける危険性は全身麻 酔時の合併症と同等の危険性があると推察される。

こうしたPSAにおいては, 薬剤による安全性の違い はなく, どれも危険なのであって, どの薬剤をどのよ うに使用するかを問う前に, 医療安全の観点からどの ような考え方，どのような姿勢，どのような体制で使 うかを問わなければならない11). 指示に従うことがで きない小児の場合, その検査や処置のリスクとは, 背 景疾患と鎮静行為の組み合わせで発生する. 鎮静のレ ベルは「一連のもの」であり，その境界は曖昧で低年歯 ほど容易に深い鎮静状態へ移行する。そのため小児に おいて鎮静のレベルに応じて安全基準を変更すること の意義は少ない11），一方，成人同様に目的とする鎮静 レベルによって異なる安全基準を設定したガイドライ ンもある6,8,19,20).

\section{PSA における小児の特殊性}

鎮静鎮痛において小児が成人と異なる点は, 疼痛や 侵襲の有無によらず協力と安静が得られない場合は鎮 静を必要とすること, 特に 6 歳以下で行動制御ができ ないため深い鎮静を必要とする場合が多いこと, 深い 鎮静では気道の開通性・咳嗽反射・呼吸抑制の傾向が あること, 計画した鎮静レベルより深い鎮静状態へ容 
Table 2 ASA Physical Status Classification

\begin{tabular}{l|l}
\hline Class I & A normally healthy patient \\
\hline Class II & A patient with mild systemic disease (eg. Controlled reactive airway disease) \\
\hline Class III & A patient with severe systemic disease (eg. A child who is actively wheezing) \\
\hline Class IV & $\begin{array}{l}\text { A patient with severe systemic disease that is a constant threat to life (eg. A child with } \\
\text { status asthmaticus) }\end{array}$ \\
\hline Class V & $\begin{array}{l}\text { A moribund patient who is not expected to survive without the operation (eg. A patient } \\
\text { with severe cardiomyopathy requiring heart transplantation) }\end{array}$ \\
\hline
\end{tabular}

Modified from ASA Physical Status Classification. (Accessed at https://www.asahq.org/clinical/physicalstatus.htm)

易に陥ること，などがあげられる。

\section{総 論}

ここでは望ましいと考えられているシステムについ て言及する. PSAの具体的内容は, 検査や処置の内容, 鎮静担当医, 検査依頼医, 緊急性, 施行場所, 使用する 薬剤の種類と量, 投入される人的物的な医療資源の違 いによって，大きく異なる. PSAにおいてある特定の 方法が優れているということはなく, 必要とする鎮静 状態に応じて管理が異なる。

1. 施行前の準備

1)検査や処置の適応とリスクの説明と同意

検査や処置を行う医師は, その必要性の判断と同時 に，PSAに伴うリスクの両方を考慮すべきである，そ してPSA についての説明と同意を得るべきである。検 查や処置の医学的適応は, 鎮静の必要性とは無関係に 判断される.したがって, 基礎疾患に伴う問題, 検査の 危険性，鎮静に伴う危険性を考慮してインフォームド。 コンセントを得る必要がある。

\section{2) 患者の評価}

鎮静担当医と検査処置実施医が異なる場合, 現病歴 や既往歴の情報共有が重要である，特に修復前もしく は姑息術後のチアノーゼ性心疾患 ${ }^{21,22)}$, 肺高血圧 症 ${ }^{23,24)}$ では注意が必要である。

PSA による主な問題は気道閉塞・呼吸停止とそれに 続く心停止であるため, それらに陥った場合の十分な 対応を想定し，以下の項目について評価する，そのう えでPSAの可否を判断する11).

(1) 問診

・年齢, 内服, アレルギーの有無(特にゼラチン, ラ テックス)

・気道閉塞に関わる因子

口腔内：いびき, 夜間覚醒, 息苦しさ, 肥満, 扁桃
ノアデノイド肥大

気道内：先天性気管狭窄, 気管・気管支軟化, 気道 異物, 気管内腫瘍

気道外：頸部リンパ管腫, 甲状腺腫瘍等, 頸部や縦 隔の腫瘍性病変

・鎮静による合併症が生じやすい基礎疾患 心疾患：先天性心疾患, うっ血性心不全, 不整脈 呼吸器疾患：睡眠時無呼吸, 気管支喘息

神経筋疾患：脳性麻瘏,ミオパチー,てんかん, 脳 室シャント

消化器疾患：胃食道逆流, 消化管狭窄

早期産児 ·低出生体重児：慢性肺疾患, 無呼吸 肝障害, 腎障害

・深鎮静が必要になる場合

注意欠陥多動性障害, 自閉症スペクトラム障害, 知 的障害

既往歴・家族歴：麻酔や鎮静による有害事象の 有無

\section{(2) 身体所見}

・体重, バイタルサイン (血圧, 脈拍数, 呼吸数, 体温, $\left.\mathrm{SPO}_{2}\right)$

・気道の評価 急性の気道感染, 鼻閉・鼻汁

顔貌異常, 扁桃肥大, 開口障害, 巨舌, 小顎, 頸部 伸展障害

\section{3）患者の選定}

全身的評価の結果から, 米国麻酔科学会の状態分類 (American society of anesthesiologist-Physical status : ASA-PS)を決定する (Table 2)。 日帰りの患者では ASAPS II 以下とし, ASA-PS III 以上では専門家に相談し, 施行の可否や入院での施行も考慮する.事前のプレパ レーションなどにより, 児の不安を解消させて協力的 に検査が遂行できる場合もあるため, 薬剤以外の介入 についても考慮する ${ }^{25,26)}$. 


\section{4) 医療従事者の配置}

PSA においては, Advanced life support skills $\left(\right.$ PALS $^{\circledR}$ など)を持つ医療従事者(医師または看護師)を，処置や 検査を行う者とは別に, 患者の監視に専念できるよう 配置する。鎮静は一連のものであり，目的とした鎮静 の深さによって異なる管理体制とするのは現実的では ない.

小児の鎮静担当医 (プロバイダー) は, 小児科医, 麻 酔科医, 救急医, 集中治療医, 看護師, 検查技師などが 行う場合がある ${ }^{15)}$. 誰が最も適切な担当者であるかは, 各国の医療体制によって報告が異なり議論が多 い16,27, 28). 患者の評価と Advanced life support が必要に 応じて可能でなければならない. 小児麻酔科医は適任 であろうが，日本では数も少なく，手術麻酔への対応 によって検査の麻酔を行うことは難しい. 現状で最も 重要なことは, 誰が行うかではなく, 適切な体制の整 備と, 人材配置, 適切なモニタリングの下に行うこと や，それら全体の訓練と教育である ${ }^{29)}$.

\section{5) 緊急時の機器・器具・薬品の配置・整備}

救命蘇生用機器・器具・薬剤を配備し, 使用できる 場所に置き, 定期的にチェックし, 必要時にはすぐに 利用可能な状態にしておく(Table 3, Table 4).

\section{6) バックアップ体制}

あらかじめ緊急事態に備えた院内急変対応チームも しくはそれに準じたシステムの形成と, 連絡経路を確 保する。

\section{7)経口摂取の制限}

PSA 前の経口摂取制限は, 全身麻酔同様に「2-4-6 ルール」が適応されることが多い6).これは飲水を 2 時 間前まで, 母乳を 4 時間前, ミルクを 6 時間前, 食事を 8 時間前までに終了とする誤嚥予防のための制限で, 予定手術患者に広く適応されている. PSA での適応に ついては一部異論もあるが30), 現状ではどのガイドラ インでも推奨されている. 緊急の場合には, 誤嚥の危 険性を考慮して, 患者のリスク, 検査や処置の緊急性, PSA の施行時間によって, 提供する鎮静レベルを制限 する方法が提唱されている31). また処置の内容によっ ては気管挿管を行う全身麻酔が安全と考えられる場合 もある. エスクレ座薬やトリクロリールシロップを鎮 静に用いる乳児の場合にも，母乳投与から時間を空け るべきである。
8)モニタリング

$\mathrm{SPO}_{2}$, 心拍数, 血圧, 呼吸数, 体温を監視できるよう にし，記録を残す。また鎮静レベルが deep では，全身 麻酔に準じて $\mathrm{EtCO}_{2}$, 胸壁聴診器の使用を行う ${ }^{3,6)}$.こ れについては異論がある32).

\section{2. 処置中}

\section{1)継続的監視と記録}

施行に当たっては, チェックリストを使用し漏れが ないことを確認する(Table 5).

鎮静レベルが moderateでは, 間欠的な観察を行い, バイタルサイン (血圧, 脈拍数, 呼吸数, 体温, $\left.\mathrm{SPO}_{2}\right)$ の 確認し，その記録を残すことが望ましいとされている。 鎮静レベルが deep では, 鎮静担当医はそれに専従し, 5 分毎のバイタルサインの確認に加え, 持続的な換気の モニタリングとして, 胸壁聴診器およびカプノグラ フィーを使用する3,6)。これらには異論もあるが，より 安全性を高めるために使用するべきである ${ }^{111}$. 目的と する鎮静レベルによって, 管理体制を変更するのは現 実的ではないため, 間欠的な観察とバイタルサイン, 可能な限りの換気モニタリングを施行することが望ま しい(Fig. 1).

\section{3. 終了後のケアと覚醒確認}

終了後は, 十分な覚醒まで間欠的な経過観察を行い, 回復基準を満たすまで監視を緩めてはならない(Table 6).

\section{各 論}

検査・処置での注意点, および各種薬剤の薬理と用 法について述べる。

\section{1. 検査別}

\section{1)心臟カテーテル検査}

痛みを伴う処置であり, 鎮静と不動化が必要で, 協 力の得られない小児においては目的とする鎮静レベル は deep sedationのことが多い. 穿刺部位には局所麻酔 薬を使用する。確実な不動化, 深い鎮静, 適切な換気の 調整とモニタリングには，全身麻酔が最適と考えられ る9)。またインターベンションを行う場合には全身麻酔 が選択されることが多い，どちらの場合にも，全身麻 酔に準じた管理体制で行うことが最も安全と考えられ る. 日本でのアンケート調査では, 約 $40 \%$ を麻酔科医 
Table 3 Checklist of equipment required for pediatric procedural sedation and analgesia

Equipment to open and protect airway

Face masks

Laryngoscope set

Endotracheal tubes

Water-soluble lubricant/KY jelly

$10 \mathrm{~mL}$ syringe

Tape, or equivalent, to tie endotracheal tube in place

Oropharyngeal airways

Nasopharyngeal airways

Equipment to confirm tracheal intubation

Stethoscope

End-tidal $\mathrm{CO}_{2}$ monitoringa

Equipment for difficult intubation

Introducers for endotracheal tubes/gum elastic bougie

Magill's forceps

Laryngeal masks

Equipment to deliver oxygen and ventilate patients

Bag-valve ventilation devices with PEEP valve adaptor

Oxygen delivery devices

Oxygen supply

Oxygen and oxygen tubing

Equipment to diagnose and treat cardiac dysrhythmias

ECG monitor defibrillator

Cardiac arrest board

Equipment to gain intravascular access

Tourniquets

Alcohol skin wipes

Sterile gauze pads

Intravenous cannulae

Needles and syringes

Sharps container

Paediatric intraosseous needles

Tape

Equipment for accurate infusion of drugs and fluids Infusion pumps

Syringe drivers

Intravenous administration sets

Intravenous fluids

Equipment for monitoring airway, breathing and circulation

Stethoscope/precordial stethoscope

Pulse oximeter

Non-invasive blood pressure monitoring device

Thermometer

Blood glucose testing

Capnograph

Miscellaneous

Drip stand, or equivalent suspension device

Suction devices and suction catheters

Therapeutic heating source

Universal precautions

Tilting operating surface or trolley

Procedure lighting

Medication stickers

Life Support Skills

\section{Resuscitation documentation record}

All equipment should be checked regularly and stored in a mobile cupboard.

It is critical for a roving or mobile sedation practitioner to ensure that all of this equipment in available before commencing sedation.
Size $0,1,2,3$ and 4

Two handles with adult and pediatric blades, and spare bulbs and

Uncuffed (sizes 2.5 - $5.5 \mathrm{~mm}$ ) Cuffed (sizes 5.0 - $7.0 \mathrm{~mm}$ )

Sizes 0-5

Sizes 6 and 7, In smaller children, one can use an endotracheal tube cut tu size in nasopharynx

Desirable, particuraly for longer, complex cases and when using advanced sedation techniques

Adult and pediatric stylets

Adult and pediatric

Sizes 1.5-3

Oxygen reservoir with adult, pediatric and neonatal masks

Masks, nebulizer masks, nasal prongs (+ $\mathrm{CO}_{2}$ monitoring) and T-piece

The oxygen source must be reliable and able to provide at least $90 \%$ oxygen via a self-inflating positive pressure delivery system, at $15 \mathrm{~L} /$ minute for at least 60 minutes

With flow regulator and oxygen tubing for bag-valve device

With conductive paste or pads, paddles, electrodes and razor

18-24 gauge

$1-50 \mathrm{~mL}$ syringes

Appropriate strapping and dressings for pediatric intravenous access

Intravenous fluid administration during simple sedation

Drug administration during advanced sedation

Administration sets and buretrol

Crystalloids and colloids

Adult and paediatric probes

Including paediatric and adult cuffs

Desirable but not compulsory: nasal prongs with capnography line

Including catheters for suctioning endotracheal tubes, and

Yankauer-type suction nozzles

Desirable for long cases

Including gloves

Capable of Fowler's and Trendelenberg positions

Adequate for intravenous access

Basic Life Support (BLS), Advanced Life Support (ALS) for adults and children, anaphylaxis management and choking spare batteries

Including low-reading capability 
Table 4 Examples of Emergency Cart

\begin{tabular}{l|l}
\hline Drugs & \\
\hline Pharmacologic Antagonists & \\
\hline & Naloxone \\
\hline Emergency medications & Flumazenil \\
\hline & Epinephrine \\
\hline & Saline \\
\hline & Muscle relaxant \\
\hline & Atropine \\
\hline & Lidocaine \\
\hline & Glucose, 50\% [20\%] \\
\hline & Diphenhydramine \\
\hline & Hydrocortisone, methylprednisolone \\
\hline
\end{tabular}

Attachment of drug charts for each body size is strongly recommended.

Table 5 Pediatric pre-procedural checklist

\begin{tabular}{|c|c|c|c|}
\hline \multirow[t]{2}{*}{ Name of patient: } & \multicolumn{3}{|l|}{ Date: } \\
\hline & & Yes & No \\
\hline \multicolumn{4}{|c|}{ 1. Has the medical history questionnaire been completed? } \\
\hline \multicolumn{4}{|c|}{ 2. Has the child been evaluated by the sedation practitioner? } \\
\hline \multicolumn{4}{|c|}{ 3. Have there been any changes in the patient's medical condition since the first evaluation? } \\
\hline \multicolumn{4}{|c|}{ If the answer is "yes", please provide details: } \\
\hline \multicolumn{4}{|c|}{ 4. Have contraindications for sedation been excluded? } \\
\hline \multicolumn{4}{|c|}{ 5. Has the child been examined for signs of an upper respiratory tract infection? } \\
\hline \multicolumn{4}{|c|}{ 6. Does the child have any allergies? } \\
\hline \multicolumn{4}{|c|}{ 7. Has the child fasted for the recommended period of time? } \\
\hline \multicolumn{4}{|c|}{ 8. Has written, informed consent been obtained? } \\
\hline \multicolumn{4}{|c|}{ 9. Has the child been administered premedication? } \\
\hline \multicolumn{4}{|c|}{ If the answer is "yes", please provide details, including the name of the practitioner who ordered it: } \\
\hline 10. Have all equi & ices, and drugs been checked? & & \\
\hline
\end{tabular}

が全身麻酔もしくは深鎮静によって管理し，小児科医 による深鎮静は $50 \%$ を占めて扮り, 麻酔科医の関与は 多くない現状が報告されている33). 全身麻酔で行う場 合, 気管挿管に伴い陽圧呼吸となること, 麻酔薬によ る血圧低下などの血行動態の修飾が問題となる. 利点 として, 確実な気道確保, 酸素濃度の正確な調整, 調節 換気，不動化があげられる。過剩な胸腔内陽圧や麻酔 薬の過量投与を避けることで血行動態への影響も最小 限にでき, 評価のための確実な状態調節が可能である. PSA としては, 局所麻酔を併用のうえで, プロポフォー ルあるいはデクスメデトミジンの単独使用や, プロポ フォールとケタミンの併用, デクスメデトミジンとケ タミンの併用などが有用である.

\section{2)心エコー(経胸壁)・CT 検査}

4 カ月未満の乳児では, 睡眠制限・哺乳・保温によ る自然睡眠後に遂行できる場合が多い，使用薬剤は， トリクロホス, 抱水クロラール, ミダゾラムなどが使 用されるが，目標の鎮静レベルは moderate 以下でよい が, 哺乳後の鎮静薬投与は禁忌である. 最近の CT 検査 はスキャン時間が短く, 抑制により鎮静がなくとも検 査可能な場合もある。主に 3 歳未満の児や精神遅滞児 では鎮静が必要である，適切な監視と記録は，他の検 查と同様必要である。

\section{3) MRI}

特殊な配慮が必要な検査である。問題点として，長 い検査時間, 狭い空間による恐怖, 95 デシベル程の騒 


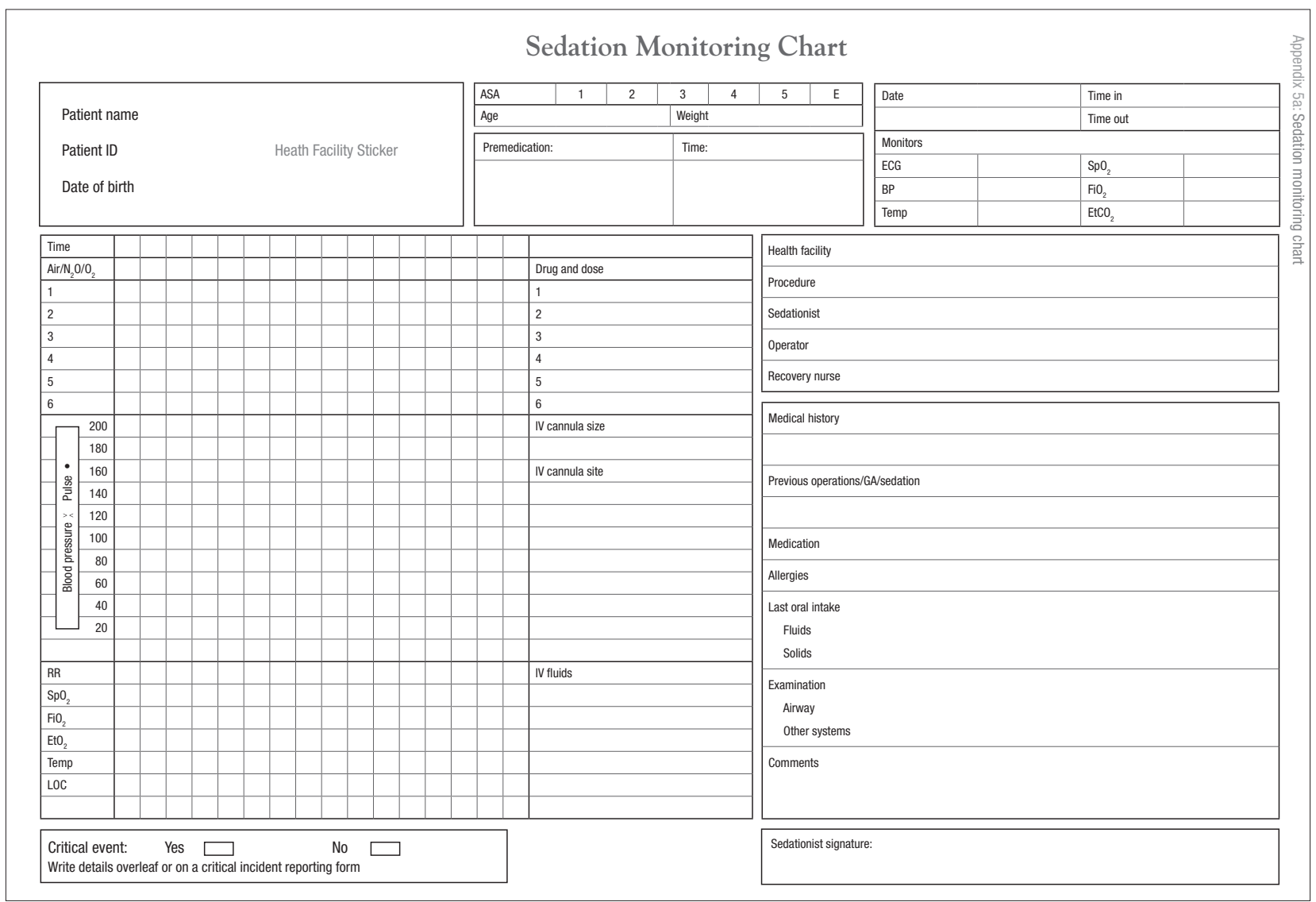

Fig. 1 Example of Monitoring chart (Modified from reference 9)

Table 6 Discharge scoring system

\begin{tabular}{|c|c|c|}
\hline Physical sign & Clinical level & Score \\
\hline \multirow{3}{*}{ Level of consciousness } & Fully awake/alert/answer questions & 2 \\
\hline & Arousable to verbal command & 1 \\
\hline & No response & 0 \\
\hline \multirow{3}{*}{ Respiration } & Able to take deep breaths and cough adequately & 2 \\
\hline & Shallow breathing with poor cough & 1 \\
\hline & Apneic periods & 0 \\
\hline \multirow{3}{*}{ Oxygen saturation* } & $>96 \%$ on room air & 2 \\
\hline & Requires oxygen to maintain saturation > 90\% & 1 \\
\hline & Saturation $<90 \%$ with oxygen & 0 \\
\hline \multirow{3}{*}{ Movement } & Able to move all four extremities on command & 2 \\
\hline & Able to move two extremities on command & 1 \\
\hline & Not able to move extremities on command & 0 \\
\hline \multirow{3}{*}{ Temperature } & $36-38{ }^{\circ} \mathrm{C}$ & 2 \\
\hline & $35.5-35.9^{\circ} \mathrm{C}$ or $38.1-38.5^{\circ} \mathrm{C}$ & 1 \\
\hline & $<35.5^{\circ} \mathrm{C}$ or $>38.5^{\circ} \mathrm{C}$ & 0 \\
\hline \multirow{2}{*}{ Pain } & Minimal discomfort or pain & 2 \\
\hline & Significant pain & 0 \\
\hline
\end{tabular}

Total score of 10 to 12 indicates that the patient can be discharged. Discharge cannot be permitted if the score for any individual category is 0 .

*Appropriate levels should be considered in each patient with heart disease 
音, MRI 適合製品の使用, 磁界によるモニターケーブ ル類の発熱, 体動の完全な抑制, MRI 室内での蘇生用 具持ち込みができないことなどがあげられる。協力の 得られない小児では, deep sedationもしくは全身麻酔 が必要である. MRIに使用可能な吸引, 酸素ボンべ, 麻 酔器などに加え, モニタリングの機器等すべてに MRI 適合機器が必要で, 事前にこれらを十分準備する必要 がある. 使用薬剤は, トリクロホス, 抱水クロラール, ミダゾラム, プロポフォールなどを用いて施行可能で ある。心臓 MRI 検査では, 呼吸相に合わせたスキャン を行うため, 検查時間が長い. 標準肺容量・無呼吸状 態とする場合には，筋弛緩薬を使用した気管挿管全身 麻酔が必要である, 疾患に応じて, 無呼吸は許容時間 内に制限する。

現状の MRI 検査室は, 鎮静を含む麻酔のことを考え た設計ではない. MRI装置自体の改善, モニタリング, 配管, シーリングなど設計段階から安心して麻酔が施 行できる環境にするべきで, “麻酔対応 MRI”の概念の 普及を望む。

\section{4)TEE（経食道心エコー）}

上部消化管内視鏡検査と同様の鎮静状態が求めら れ, 協力の得られない小児では deep sedation が必要で ある.プローべによる気道閉塞, 息こらえや, 嘔吐など の危険性があるため, 注意深い観察と評価が不可欠で ある。リドカインを用いた粘膜麻酔を併用してもよい。

2. 薬剂別 34)

\section{1) 鎮痛薬}

\section{(1) ケタミン}

使用法: 静注, 筋注, 経直腸投与などの報告がある. 静注では, 初回量 1〜2 mg/kg を 1 分以上かけて緩徐 に投与する. 投与後 60 秒程度で意識消失, その後 20 分程度持続する麻酔状態が得られる。必要に応じて初 回量と同量または半量を追加投与する。全身麻酔時に は, $0.25 \sim 0.5 \mathrm{mg} / \mathrm{kg} / \mathrm{hr}$ の持続静注を行ってもよい. 覚 醒後も意識状態の全回復には 60 分程度を要する。筋注 では, $4 \sim 8 \mathrm{mg} / \mathrm{kg}$ の投与で, 4 分程度で麻酔状態が得 られ, 30 分程度作用が持続する. 必要に応じて初回量 と同量か半量を追加投与する. 経直腸投与では, 麻酔 前投薬として $5 \sim 10 \mathrm{mg} / \mathrm{kg}$ を投与するが, 十分な作用 発現に 45 分を要するが, 覚醒に必要な時間も延長する。

薬効・薬理作用：新皮質や皮質下領域に抑制的に作 用する一方, 辺縁系を活性化する解離性麻酔薬である. 脊髄後角の NMDA 受容体に対する非競合的拮抗薬で,
皮膚, 筋肉, 骨などの体性痛の痛みに対する強い鎮痛 作用を有する. 投与後 5 分以内に一過性の血圧や頻拍 が見られることがある. 投与後 $2 \sim 3$ 分で軽度の呼吸 抑制があらわれるが一過性で, 急速静注では, 呼吸停 止や筋緊張光進がみられることがある. 脳血流が増加 し, 頭蓋内圧上昇作用を有するが, 投与後 20 分で前值 に戻る.

薬物動態: 投与後に速やかに脳, 体脂肪, 肝臓など へ移行し, 生物学的半減期は 4 時間, 代謝経路は肝臓 のチトクロームP450でその活性代謝産物ノルケ夕ミ ンはケタミンの $1 / 3$ 程度の効果を持つ. 持抱合代謝産 物が腎から排泄される。

適応: 添付文書上の適応は, 手術・検査扮よび処置 時の全身麻酔および吸入麻酔の導入である, その他に 処置・検查の鎮静に拝いても広く使用されている.

心臓カテーテル検査に使用される ${ }^{35)}$. 痛みを伴わな い画像検査時の鎮静では, しばしば不随意運動が問題 となるため推奨されない.

\section{(2)フェンタニル}

使用法: 主に静注で使用し, 1 4 ug/ $/ \mathrm{kg}$ で気管挿管 時の血行動態の反応が減弱する. 術後疼痛では $1 \sim 2$ $\mathrm{ug} / \mathrm{kg}$ を緩徐に静注する。いずれも呼吸モニタリングを 行える体制が必要である.

薬効・薬理作用: 脳幹と春髄のオピオイド $\mu$ 受容体 に作用する強力な鎮痛薬を示すと共に, 呼吸抑制, 徐 脈, 嘔気, 便秘等をもたらす. 作用発現は迅速で, 作用 時間は 30 分から 1 時間, 反復投与による蓄積がみられ る。血圧低下作用はゆるやかで，心筋抑制作用がない ため, 血行動態が不安定な患者にも使用できる，急速 静注によって鉛管現象として呼吸抑制が生じるため, 緩徐に投与し，十分な気道管理が可能な部署で使用す ることが望ましい.

薬物動態：肝代謝で不活化され，一部は腎臓から排 泄される。

適応：添付文書上の適応は, 全身麻酔における鎮痛, 局所麻酔における鎮痛の補助, 激しい疼痛(術後疼痛, 癌性疼痛など)に対する鎮痛である。重要な基本的注意 として, 必ず気道確保・呼吸管理等の蘇生設備が完備 された場所で厳重な管理の下にしようすること, そし て呼吸管理が十分に行える麻酔時以外に使用しないこ とという記載があり，一般病棟での鎮痛目的に安易に 使用すべきではない.

先天性心疾患においては, 主に心内修復手術時の麻 酔に使用されることが多い. 国外での報告では小児の PSA においても使用される16,36). 
(3)ペンタゾシン

使用法：静注もしくは筋注・皮下注で使用する. 静 注では $0.5 \mathrm{mg} / \mathrm{kg}$, 筋注・皮下注では $1 \mathrm{mg} / \mathrm{kg}$ を投与する.

薬効・薬理作用： $\kappa$ オピオイド受容体作動薬で, $\mu$ オピオイド受容体の拮抗薬である. 強力な鎮痛作用と 弱いオピオイド拮抗作用があり，成人では $30 \sim 70 \mathrm{mg}$ の投与で, 鎮痛作用および呼吸抑制作用に天井効果が 生じる. 呼吸抑制, 心収縮力抑制, 嘔気など起こる可能 性がある.1 歳未満の乳児に対しては安全性が確立し ていない.

薬物動態：成人とほぼ同じであり，投与間隔は成人 と同様である。筋注での最高鎮痛効果は 1 時間以内, 静注では 15 分以内であるが, 個体差が大きい.

適応：添付文書上の適応は, 鎮痛, 麻酔前投薬 - 麻 酔補助である。

その他：主に術後痛で使用され, PSA としての使用 報告は少ない。

\section{(4) ブプレノルフィン}

使用法：直腸内投与, 静注で使用する. 静注では 4 $\mathrm{ug} / \mathrm{kg}$ を $6 \sim 8$ 時間以上の間隔をあけて投与する.

薬効・薬理作用： $\mu$ オピオイド受容体の部分作用薬, $\kappa$ 受容体の拮抗薬として作用し, 中枢性鎮痛作用を示 し, 半減期 166 分, 作用時間 10 時間と長い.オピオイ ド受容体拮抗薬のナロキソン投与で容易に拮抗されな い. 成人では $0.15 \sim 1.2 \mathrm{mg}$ で効果と副作用の上限(天 井効果)を示すとされる. 小児ではこの天井効果はな く，用量依存性に副作用がみられるため特に呼吸抑制 に対して注意が必要である。

薬物動態：脂溶性が高く, 受容体からの解離に時間 を要するため, 鎮痛作用の持続時間が長いとされる. 主に肝臓で代謝され，主に胆汁経由で糞中に排泄さ れる。

適応：添付文書上では, 各種癌に扮ける鎮痛, 麻酔 の補助, 術後疼痛が適応である。

その他：小児に対する安全性は確立していないとさ れる。

\section{(5) ナロキソン}

使用法：主に静注で使用する。単回投与では $1 \sim 10$ $\mathrm{ug} / \mathrm{kg}$ を必要に応じて投与する。遷延性呼吸抑制では, $2 \sim 10 \mathrm{ug} / \mathrm{kg} / \mathrm{hr}$ で持続投与する.オピオイド中毒では $0.1 \mathrm{mg} / \mathrm{kg}$ を投与する場合がある.

薬効・薬理作用：オピオイド受容体 $(\mu, \kappa, \delta)$ に おける競合的拮抗作用を持ち，主に $\mu$ 受容体に対して 高い親和性を持つ.モルヒネ, フェンタニルの静注に
よる呼吸抑制作用に拮抗する。効果発現は 3 分以内, ピークは $5 \sim 15$ 分で, オピオイドの鎮静状態, 低血圧 にも拮抗するが, 30 分で効果は著しく減少する。

薬物動態：血漿半減期は $30 \sim 90$ 分, 肝臓で抱合さ れ，尿中へ排泄される。

適応：適応はオピオイド(フェンタニル，モルヒネ， ペンタゾシン,ブプレノルフィンなど)による呼吸抑 制, 覚醒遅延である。

\section{(6) 局所麻酔薬 (リドカイン)}

アミド型の局所麻酔薬で，0.5 2.0\%を局所浸潤麻 酔として使用する。作用時間は $30 \sim 90$ 分で, 極量は 5 $\mathrm{mg} / \mathrm{kg}$ である。粘膜への表面麻酔として使用する場合 は, キシロカイン®ポンプスプレー 8\%あるいはジャク ソン型噴霧器によるキシロカイン液 ${ }^{\circledR} 4 \%$ の噴霧が使用 可能だが，極量を超えないよう総投与量に十分な注意 が必要である。

リドカイン溶液は $\mathrm{pH} 4.95$ と酸性で, 局所注入時に灼 熱感を伴う疼痛があり, 鎮静下の小児でも体動を起こ すことがある。リドカインと重炭酸ナトリウムを 10 : 1 で混合すれば, 溶液 $\mathrm{pH}$ は 7.54 と上昇し注入時の痛み が軽減される、ペンレス ${ }^{\circledR} は$ 穿刺予定部位に塗布する ことで, 穿刺部の疼痛軽減に有用である.

エムラ®クリームは, リドカインとプロピトカイン の合剤で,フィルムドレッシング $10 \mathrm{~cm}^{2}$ あたり $1 \mathrm{~g}$ を 塗布密閉することで, 60 分後に効果がみられる. 添付 文書上の適応はレーザー治療となっているが, 使用量 の上限は, $0 \sim 3$ カ月または $5 \mathrm{~kg}$ 未満で $1 \mathrm{~g}, 4 \sim 12$ カ 月および $5 \mathrm{~kg}$ 以上で $2 \mathrm{~g}, 1 \sim 6$ 歳で $10 \mathrm{~g}, 7$ ～ 12 歳で $20 \mathrm{~g}$ とされる26).

\section{2) 鎮静薬}

(1) トリクロホス $\left(\right.$ トリクロリール ${ }^{\circledR}$ シロップ)

使用法：経口投与で $20 \sim 80 \mathrm{mg} / \mathrm{kg}$ を使用し, 上限 は $2 \mathrm{~g}$ である.

薬効・薬理作用：主に GABA 受容体に作用し, $\mathrm{Cl}$ イ オンチャネルの開口を促進し, 中枢性鎮静作用を発揮 する. 鎮痛作用はない.

薬物動態：分子量 251, 胃粘膜で吸収され, 肝臓で薬 物活性を持つトリクロロエタノールに分解され，グル クロン酸抱合を受けた後に尿中へ排泄される。作用発 現は $30 \sim 60$ 分, 持続時間は $2 \sim 8$ 時間である. 成人 のトリクロロエタノールの半減期は 8.2 時間, 生後 4 カ 月以上の小児の半減期 9.6 時間であるが, 新生児では 28 時間, 未熟児では 40 時間と比べて著しく長いため, 慎重な投与と入院での検査が安全である。 
適応：検查等における睡眠が適応である.

\section{(2) 抱水クロラール (エスクレ ${ }^{\circledR}$ 坐剂)}

使用法：直腸内投与で, $30 \sim 50 \mathrm{mg} / \mathrm{kg}$ を標準とし, 上限 $1.5 \mathrm{~g}$ を超えないように使用する.

その他：分子量 165 , 肝臓のアルコール脱水素酵素 によりトリクロロエタノールに分解されて活性を発揮 し,トリクロホスと同様の注意が必要である。

\section{(3)ミダゾラム}

使用法：経口，経直腸，筋注，鼻腔内, 静注として使 用される. 経口では, $0.5 \mathrm{mg} / \mathrm{kg}$, 経直腸では $0.2 \sim 1.0$ $\mathrm{mg} / \mathrm{kg}$, 最大 $20 \mathrm{mg}$ を使用する。筋注では $0.1 \sim 0.15$ $\mathrm{mg} / \mathrm{kg}$, 鼻腔内では $0.2 \sim 0.3 \mathrm{mg} / \mathrm{kg}$ を使用するが, 痛み や不快を伴うためやむを得ない場合のみに使用する。 鎮静のための静注では, 6 カ月から 5 歳までは, 初回 0.05 $\sim 0.1 \mathrm{mg} / \mathrm{kg}$ で総投与量 $0.6 \mathrm{mg} / \mathrm{kg}$ まで, 通常 $6 \mathrm{mg}$ を超 えない. 6 歳から 12 歳までは, $0.025 \sim 0.05 \mathrm{mg} / \mathrm{kg}$ で総 投与量 $0.4 \mathrm{mg} / \mathrm{kg}$ まで, 通常 $10 \mathrm{mg}$ を超えない. 12 歳以 上は成人と同じである。全身麻酔における麻酔導入で は, $0.15 \mathrm{mg} / \mathrm{kg}$ を緩徐に静注する。

薬効・薬理作用：中枢神経系の GABA 受容体を賦活 し, Cl イオンチャネルの開口頻度を上昇させ, 鎮静効 果と抗痓攣作用を発揮する。

薬物動態：肝臓のチトクローム P450で代謝され, 6 カ月以上で半減期は 3 時間程度であるが, 未熟児や 新生児では半減期は 7.6 時間と長い。また患者ごとの ばらつきも大きい。

適応：添付文書上の適応は, 麻酔前投薬, 全身麻酔 の導入および維持，口腔外科領域における手術および 処置時の鎮静となっており, 検査や処置の際の鎮静や 㾏攣の治療として記載はない。

その他：呼吸抑制，循環抑制が見られる場合があり， 適切な医師の監視下に打いてのみ使用する。また他の 中枢神経系抑制薬との併用で, 作用が増強して低換気 や気道閉塞を来し得るため慎重投与が必要である.

\section{(4) プロポフォール}

使用法：小児では $2 \sim 4 \mathrm{mg} / \mathrm{kg}$ の静注で麻酔導入が 可能である. 全身麻酔の維持では, $60 \sim 200 \mathrm{mcg} / \mathrm{kg} /$ min を用いることが可能であり，反応によって投与量 を調整する.小巟の人工呼吸中の鎮静においては, 稀 であるがプロポフォール症候群(propofol infusion syndrome：PRIS)の可能性があるため禁忌となってい る. PRIS は, 小児において $4 \mathrm{mg} / \mathrm{kg} / \mathrm{hr}$ 以上の使用量で, 48 時間以上使用することにより発症する危険性が高い
と報告された ${ }^{37)}$. 成人例やより短時間での発症例もあ り発生機序は不明であるが, 主にミトコンドリアでの 脂質代謝異常の可能性が指摘される。使用期間は長時 間を避け, 経過中に乳酸アシドーシスを認めた場合は 速やかに中止するべきである38).

薬効・薬理作用：GABA 受容体を賦活し, NMDA 受 容体を抑制し, 中枢神経系に抑制的に働く。催眠, 鎮静, 抗不安作用があるが鎮痛作用はない。呼吸抑制が著明 で，オピオイドの併用で増強される，心血管系では，心 拍出量の減少と体血管抵抗の低下を伴い, 血圧は低下 する。

薬物動態: 作用発現, 持続時間共に短く, 分布半減 期が $2 \sim 8$ 分で, 持続静注による半減期の増加がほと んど見られない. 主に肝臟で抱合され，腎より排泄さ れ，活性のある代謝産物はない，尿中の尿酸排泄が増 加し, 変色尿となることがある.小児では分布容積が 大きくクリアランスも早いため, 成人に比べて多量が 必要であるが蓄積作用は少ない。

適応：添付文書上の適応は，全身麻酔の維持および 導入となっている。

(5) バルビッール酸 (チオペンタールナトリウム, チア ミラールナトリウム)

使用法：静注および直腸内投与が可能である。静注 では, 新生児で $3 \sim 5 \mathrm{mg} / \mathrm{kg}$, 小児で $5 \sim 6 \mathrm{mg} / \mathrm{kg}$ で麻 酔導入ができる. 直腸内投与では $20 \sim 50 \mathrm{mg} / \mathrm{kg}$ を投 与し, 15 分程度で入眠が得られ, 1 時間程度の効果持 続が見られる。

薬効・薬理作用：GABA 受容体と結合し, $\mathrm{Cl}$ チャネ ルの開口を増強させ, 鎮静・催眠作用を起こす。容量 依存性に脳代謝を抑制し, 脳血流用と頭蓋内圧を低下 させる。鎮痛作用はない.

薬物動態：単回投与後は, 再分布によって速やかに 血中濃度が低下するが, 排泄半減期は小肾で 6.1 時間 である、肝代謝である. $0.3 \mathrm{mg} / \mathrm{kg} / \mathrm{min}$ を超える持続投 与によって組織内濃度が飽和し, 血中濃度は増加し続 けるため著しい覚醒遅延を生じる。

適応：添付文書上の適応は, 全身麻酔の導入, 局所 麻酔剤・吸入麻酔剂との併用, 子痾等に伴う痤攣とさ れる。

その他：アルカリ性が高く $\mathrm{pH} 10.5$ で, 動脈内注射や 血管外漏出では組織壊死が問題となる。呼吸抑制, 循 環抑制が見られるため, 基本的蘇生措置に精通した医 師の監視下に扔いて適切なモニタリング下に使用する べきで，十分な回復まで観察を続ける。 
(6) デクスメデトミジン

使用法：成人では $6 \mathrm{ug} / \mathrm{kg} / \mathrm{hr}$ の投与速度で 10 分間の 静脈内持続注入し(初期負荷投与), 維持量として 0.2 $0.7 \mathrm{ug} / \mathrm{kg} / \mathrm{hr}$ の範囲で使用する. 単独で小児に充分な鎮 静を得る場合は $1 \mathrm{ug} / \mathrm{kg} / \mathrm{hr}$ 程度以上の高容量を必要と するが失敗する場合も多く，他剤との併用が必要であ る $^{39,40)}$.

薬効・薬理作用：ａ２アドレナリン受容体作動薬で, 青斑核や脊髄を作用部位として, 鎮静作用, 弱い鎮痛 作用，交感神経抑制作用を持つ。健忘作用は弱く，呼吸 抑制作用が少なく, 自然睡眠に近い鎮静状態とされる。

薬物動態：肝代謝で $95 \%$ が腎排泄され, 腎機能低下 患者では効果が遷延する. 分布半減期は 6 分, 排泄半 減期は 2 時間, 血中半減期は 2.4 時間である。これらは 小児にも当てはまる。一過性の高血圧, 容量依存性の 徐脈が見られる。

適応：添付文書上の適応は, 集中治療における人工 呼吸中及び離脱後の鎮静, 局所麻酔下に抢ける非挿管 での手術及び処置時の鎮静とされている.

\section{まとめ}

PSA をシステムとして捉えた体制の整備と医療資源 の配分, 国内での鎮静ガイドラインの作成, 薬剂の適応 拡大などが必要である。

\section{【参考文献】}

1) Cote CJ: Pediatric Sedation Guidelines: Where Have We Come from and Where Are We Going? What Are the Current Concerns? 日小巟麻酔会誌 $2009 ; 15 ： 34-44$

2) Cote CJ, Notterman DA, Karl HW, et al: Adverse sedation events in pediatrics: a critical incident analysis of contributing factors. Pediatrics $2000 ; \mathbf{1 0 5}: 805-814$

3) ADVISORY ON GRANTING PRIVILEGES FOR DEEP SEDATION TO NON- ANESTHESIOLOGIST SEDATION PRACTITIONERS. 2010. (Accessed at https://www.asahq. org/For-Members/Standards-Guidelines-and-Statements. aspx)

4)STATEMENT ON GRANTING PRIVILEGES TO NONANESTHESIOLOGIST PHYSICIANS FOR PERSONALLY ADMINISTERING OR SUPERVISING DEEP SEDATION. 2012. (Accessed at https://www.asahq. org/For-Members/Standards-Guidelines-and-Statements. aspx)

5) Australian and New Zealand College of Anaesthetists: Guidelines on Sedation and/or Analgesia for Diagnostic and
Interventional Medical, Dental or Surgical Procedures. (Accessed at http://www.anzca.edu.au/resources/professionaldocuments/pdfs/ps09-2010-guidelines-on-sedation-and-oranalgesia-for-diagnostic-and-interventional-medical-dentalor-surgical-procedures.pdf)

6) Cote CJ, Wilson S: Guidelines for monitoring and management of pediatric patients during and after sedation for diagnostic and therapeutic procedures: an update. Pediatrics 2006; 118: 2587-2602

7) National Institute for Health an Clinical Excellence: Sedation in children and young people. 2012. (Accessed at http://www.nice.org.uk/guidance/CG112)

8) Scottish Intercollegiate Guidelines Network: Safe Sedation of Children Undergoing Diagnostic and Therapeutic Procedures. 2004. (Accessed at http://www.google.co.jp/url?s $\mathrm{a}=\mathrm{t} \& \mathrm{rct}=\mathrm{j} \& \mathrm{q}=\&$ esrc $=\mathrm{s} \&$ source $=$ web $\& \mathrm{~cd}=1 \& \mathrm{ved}=0 \mathrm{CCEQFj}$ AA\&url=http $\% 3 \mathrm{~A} \% 2 \mathrm{~F} \% 2 \mathrm{Fwww}$.gosh.nhs.uk\%2FEasySite Web\%2FGatewayLink.aspx\%3FalId\%3D81040\&ei=HQ RU6L6LJL-8QXdxIGACQ\&usg=AFQjCNEgZFgVL_0X51 B9Nn_83C7xJpO_QQ\&sig2=-h8OkYhtnQA4PhR5djVsPA \&bvm=bv.71667212,d.dGc)

9) The Official Journal of the South African Society of Anaesthesiologists: Guidelines for the safe use of procedural sedation and analgesia for diagnostic and therapeutic procedures in children: 2010. 2010. (Accessed at http://www. sasaweb.com/content/images/Sedation_Guidelines_ Paediatrics.PDF)

10) Krauss B, Green SM: Procedural sedation and analgesia in children. Lancet 2006; 367 : 766-780

11) 日本小児科学会: MRI検査時の鎮静に関する共同提言. 2013. (Accessed at http://www.jpeds.or.jp/modules/ guidelines/index.php?content_id=33)

12) POSITION ON MONITORED ANESTHESIA CARE. 2013. (Accessed at https://www.asahq.org/For-Members/ Standards-Guidelines-and-Statements.aspx)

13) American Society of Anesthesiologists Task Force on Sedation and Analgesia by Non-Anesthesiologists: Practice guidelines for sedation and analgesia by nonanesthesiologists. Anesthesiology 2002；96：1004-1017

14)黒田 勲:「信じられないミス」はなぜ起こるーヒュー マン・ファクターの分析. 東京: 中災防新書; 2001

15)勝盛 宏, 阪井裕一, 草川 功, ほか: MRI検査を行う小 児患者の鎮静管理に関する実態調查. 日小児会誌 2013; 117: 1167-1171

16) Cravero JP, Blike GT, Beach M, et al: Incidence and nature of adverse events during pediatric sedation/anesthesia for procedures outside the operating room: report from the Pediatric Sedation Research Consortium. Pediatrics 2006; 118: 1087-1096

17) Cravero JP, Beach ML, Blike GT, et al: The incidence and nature of adverse events during pediatric sedation/ anesthesia with propofol for procedures outside the operating room: a report from the Pediatric Sedation 
Research Consortium. Anesth Analg 2009; 108: 795-804

18)Flick RP, Sprung J, Harrison TE, et al: Perioperative cardiac arrests in children between 1988 and 2005 at a tertiary referral center: a study of 92,881 patients. Anesthesiology 2007; 106: 226-237; quiz 413-414

19)STATEMENT ON GRANTING PRIVILEGES FOR ADMINISTRATION OF MODERATE SEDATION TO PRACTITIONERS WHO ARE NOT ANESTHESIA PROFESSIONALS. 2011. (Accessed at https://www.asahq. org/For-Members/Standards-Guidelines-and-Statements. aspx)

20) Guidelines for the elective use of conscious sedation, deep sedation, and general anesthesia in pediatric patients. Committee on Drugs. Section on anesthesiology. Pediatrics 1985; 76: 317-321

21) Ramamoorthy C, Haberkern CM, Bhananker SM, et al: Anesthesia-related cardiac arrest in children with heart disease: data from the Pediatric Perioperative Cardiac Arrest (POCA) registry. Anesth Analg 2010; 110: 13761382

22) Diaz LK, Jones L: Sedating the child with congenital heart disease. Anesthesiol Clin 2009; 27 : 301-319

23) Twite MD, Friesen RH: The Anesthetic Management of Children with Pulmonary Hypertension in the Cardiac Catheterization Laboratory. Anesthesiol Clin 2013.

24) Taylor CJ, Derrick G, McEwan A, et al: Risk of cardiac catheterization under anaesthesia in children with pulmonary hypertension. Br J Anaesth 2007; 98: 657-661

25) 原田香奈, 相吉 恵, 祖父江由紀子: 医療を受ける子ど もへの上手なかかわり方. 東京: 日本看護協会出版; 2013

26)堀本 洋, 木内恵子, 諏訪まゆみ: こどもの検査と処置 の鎮静・鎮痛. 東京: 中外医学社; 2013

27) Wetzel RC: Who is doing what to whom: a large prospective study of propofol anesthesia in children. Anesth Analg 2009; 108: 695-698

28) Couloures KG, Beach M, Cravero JP, et al: Impact of provider specialty on pediatric procedural sedation complication rates. Pediatrics $2011 ; 127$ : e1154-1160

29) Verghese ST, Martin GR: Heavy sedation versus general anesthesia for pediatric invasive cardiology: a Grayer shade of blue versus a pinker shade of pale? Pediatr Cardiol 2003; 24: 193-194

30) Mace SE, Brown LA, Francis L, et al: Clinical policy: Critical issues in the sedation of pediatric patients in the emergency department. Ann Emerg Med 2008; 51: 378399, 399. e1-57

31) Green SM, Roback MG, Miner JR, et al: Fasting and emergency department procedural sedation and analgesia: a consensus-based clinical practice advisory. Ann Emerg Med 2007; 49: 454-461

32) Green SM, Pershad J: Should capnographic monitoring be standard practice during emergency department procedural sedation and analgesia? Pro and con. Ann Emerg Med $2010 ; \mathbf{5 5}: 265-267$

33) 三浦 大, 賀藤 均, 安河内聡, ほか: 小児心藏カテーテ ル検査・治療の深鎮静に関する全国調査. 日小児循環 器会誌 $2013 ； 29 ：$ s187

34) 日本麻酔科学会: 小览麻酔薬. 麻酔薬および麻酔関連 薬使用ガイドライン第3版. 2012. (Accessed at http:// www.anesth.or.jp/guide/index.html)

35) Jobeir A, Galal MO, Bulbul ZR, et al: Use of low-dose ketamine and/or midazolam for pediatric cardiac catheterization. Pediatr Cardiol 2003; 24: 236-243

36) Lasky T, Ernst FR, Greenspan J: Use of analgesic, anesthetic, and sedative medications during pediatric hospitalizations in the United States 2008. Anesth Analg 2012; 115: 1155-1161

37) Bray RJ : Propofol infusion syndrome in children. Paediatr Anaesth 1998; 8: 491-499

38) Fudickar A, Bein B, Tonner PH: Propofol infusion syndrome in anaesthesia and intensive care medicine. Curr Opin Anaesthesiol 2006; 19: 404-410

39) Tobias JD, Gupta P, Naguib A, et al: Dexmedetomidine: applications for the pediatric patient with congenital heart disease. Pediatr Cardiol 2011; 32: 1075-1087

40) Tobias JD: Dexmedetomidine and ketamine: An effective alternative for procedural sedation? Pediatr Crit Care Med $2012 ; \mathbf{1 3}: 423-427$ 